\title{
Altered Nitrogen Availability in Pea-Barley Sole- and Intercrops Changes Dominance of Two Nitrophilic Weed Species
}

\author{
Ortrud Jäck *, James Ajal (D) and Martin Weih
}

Citation: Jäck, O.; Ajal, J.; Weih, M. Altered Nitrogen Availability in Pea-Barley Sole- and Intercrops Changes Dominance of Two Nitrophilic Weed Species. Agronomy 2021, 11, 679. https://doi.org/ 10.3390 /agronomy11040679

Academic Editors: Ilias Travlos, Nicholas Korres and Rafael De Prado

Received: 2 March 2021

Accepted: 31 March 2021

Published: 2 April 2021

Publisher's Note: MDPI stays neutral with regard to jurisdictional claims in published maps and institutional affiliations.

Copyright: (c) 2021 by the authors. Licensee MDPI, Basel, Switzerland. This article is an open access article distributed under the terms and conditions of the Creative Commons Attribution (CC BY) license (https:/ / creativecommons.org/licenses/by/ $4.0 /)$.
Department of Crop Production Ecology, Swedish University of Agricultural Sciences, Box 7043, SE-75007 Uppsala, Sweden; james.ajal@slu.se (J.A.); martin.weih@slu.se (M.W.)

* Correspondence: ortrud.jack@slu.se; Tel.: +46-18-67-2310

\begin{abstract}
Effective and sustainable weed management in agricultural fields is a prerequisite for increasing crop yield without negatively impacting the environment. The aim of this study was to explore how varying nitrogen $(\mathrm{N})$ availability in cropping arrangements of pea (Pisum sativum) and barley (Hordeum vulgare) grown as sole crops and intercrops at different fertilization levels and considering different $\mathrm{N}$ sources (soil mineralization, $\mathrm{N}$ fixation, $\mathrm{N}$ fertilizer) affects the response of weed species with differential $\mathrm{N}$ responsiveness. Crop and weed biomass were sampled at flowering and maturity. The total $\mathrm{N}$ content and ${ }^{15} \mathrm{~N}$ isotope signatures were analyzed to differentiate between $\mathrm{N}$ sources and to estimate the amount of $\mathrm{N}$ available to weeds. The highly $\mathrm{N}$-responsive weed (Chenopodium album) accumulated more $\mathrm{N}$ and biomass than the weed with reduced $\mathrm{N}$ responsiveness (Galeopsis spp.). Fertilizer supply favored Chenopodium album, but not the crops. Altered soil $\mathrm{N}$ availability caused a shift in the dominance of the nitrophilic weed species towards the highly $\mathrm{N}$-responsive species. This shift in dominance could affect the long-term weed community composition and thus have implications for sustainable weed management.
\end{abstract}

Keywords: crop-weed interaction; nitrogen availability; intercropping; weed nitrogen uptake; ${ }^{15} \mathrm{~N}$; plant-plant interaction; isotope technique

\section{Introduction}

Weed management has always been an important part of agriculture and can be considered a specific case of vegetation management, in which various techniques are used to manage plant populations in a given area. Thus, weed management actions attempt to manipulate crop-weed populations to the benefit of the crop plants. The effects of weeds on crop plants can be variable, depending on the identities of the crop and weed species that form part of the plant community, and the most common influence of weeds on crops is competition for available resources (e.g., light, water, nutrients). In light of a growing population, sustainable solutions are necessary to maintain or increase crop yields, but also foster effective weed management options to provide nutrition without jeopardizing the environment [1,2]. As such, intercropping has been proposed as a system to simultaneously increase crop yields and benefit the environment, particularly cereal-legume intercrops [2,3]. The combination of these two functionally different crops is especially beneficial due to their complementarity in nitrogen (N) acquisition, i.e., $\mathrm{N}$-fixation by the legume component and strong $\mathrm{N}$ demand by the cereal component, and by increasing the competitiveness of the legume crop against weeds when intercropped with a competitive cereal partner. The complementarity in $\mathrm{N}$ acquisition can be expected to alter soil $\mathrm{N}$ availability in cereal-legume intercrops compared to the corresponding sole crops, which, in turn, can affect weed competition as demonstrated for pea-barley intercrops [4,5]. Besides altered N availability in intercrops, altered light interception through changes in canopy structure can affect weed competition [6]. 
Too often, weeds are regarded as homogenous group of species. Most agronomical studies analyzing competition effects on weeds do not take into account the very diverse nature of this group, and they only measure a composite response of all weeds. Indeed, most of the arable weeds are adapted to disturbances, follow short life cycles with high seed production and high growth rate, and can therefore be classified as ruderals or competitiveruderals following Grime's C-S-R scheme [7,8]. However, large variation in functional traits has been found within the group of ruderals, requiring finer classification schemes for weeds to capture their variation for effective sustainable weed management $[9,10]$. Although the weed flora in intensively managed agricultural fields is adapted to high nutrient input that favors species with nitrophilic traits [11,12], individual weed species significantly differ in their responses to $\mathrm{N}$ in terms of both root and shoot growth and soil $\mathrm{N}$ acquisition, making the individual species' response to $\mathrm{N}$ a crucial factor for crop-weed competition and effective weed management [13].

In general, the poor documentation of the variation in the ecological responses among individual weed species significantly hampers the development of predictive ecological theory and subsequent development of ecological weed management strategies. Specifically, the existence of great functional trait differences among weed species raises the question whether individual weed species that commonly occur, and are adapted to high input management, vary in their $\mathrm{N}$ uptake and growth responses to cropping arrangements that provide different levels of soil $\mathrm{N}$ availabilities, e.g., by including pure and mixed cultures of legumes (N-fixing) and cereals grown at contrasting nutrient levels. In order to systematically explore differential weed responses to $\mathrm{N}$ in a cropping arrangement providing different soil nutrient levels, we here define two types of weeds: species with a high capability to acquire soil $\mathrm{N}$ (i.e., high $\mathrm{N}$ responsiveness-HNR), and those with reduced responsiveness to $\mathrm{N}$ and lower capability for soil $\mathrm{N}$ acquisition (i.e., reduced $\mathrm{N}$ responsiveness-RNR). Two dominant weed species, Chenopodium album $\mathrm{L}$. and Galeopsis spp., are common and competitive weeds in Swedish spring cereals [14,15] and are used to represent the two contrasting weed groups, i.e., HNR and RNR species respectively, in this study. The Galeopsis spp. present in the study region are the species Galeopsis tetrahit L., Galeopsis bifida BOENN., and Galeopsis speciosa MILL., which are difficult to distinguish before flowering and do also occur together. Therefore, Galeopsis spp. were accounted for on genus level in this study. Both C. album and G. tetrahit are nitrophilous species with Ellenberg values for $N$ ranging between 6 and 8 [16]. Despite these two species often occurring together and being similar in terms of nitrophily, C. album and G. tetrahit, as representatives of the genus, showed distinct responses to added $\mathrm{N}$ under controlled conditions [13]:

Chenopodium album could extract more than $90 \%$ of the available soil $\mathrm{N}$ even at high levels of $\mathrm{N}$ availability, whereas $\mathrm{G}$. tetrahit extracted similar proportions at lower $\mathrm{N}$ levels but cannot maintain this level of extraction as $\mathrm{N}$ availability increased. The two weeds also differ in their responses of root biomass to increasing $\mathrm{N}$ availability, with $\mathrm{C}$. album showing a stronger increase in root biomass than G. tetrahit. Therefore, C. album is referred to as HNR species, while Galeopsis spp. is referred to as RNR species, due to its comparably reduced responsiveness to $\mathrm{N}$.

The overall aim was to investigate the capability of two types of weeds (i.e., HNR and RNR) to accumulate biomass and $\mathrm{N}$ under conditions of differential soil $\mathrm{N}$ availabilities and $\mathrm{N}$ sources (e.g., soil mineralization, $\mathrm{N}$ fixation, $\mathrm{N}$ fertilizer) in a cropping arrangement of pea-barley intercrops and sole-crops that were grown with and without additional $\mathrm{N}$ supply. Based on the differential responses of the two weed types to $\mathrm{N}$, and assuming that the supplied fertilizer $\mathrm{N}$ will readily be available only for a limited amount of time (leaching, uptake) while mineralized soil $\mathrm{N}$ will be supplied continuously at lower amounts, the following hypotheses were tested: 
1. Weed biomass generally decreases with increasing leaf area index, shoot biomass and canopy height of the crops; but the positive effect of increased $N$ availability on weed biomass accumulation is stronger than the weed suppression effects of the crop canopy traits.

2. The HNR species accumulate proportionally more biomass and $N$ than the RNR species in the cropping arrangements providing higher soil $\mathrm{N}$ availability; furthermore, the HNR species recover larger amounts of fertilizer N, but extract a higher proportion of their accumulated $\mathrm{N}$ from soil compared to the RNR species.

3. The increased biomass and $\mathrm{N}$ accumulation of the HNR species compared to the RNR species is due to their stronger growth and $\mathrm{N}$ accumulation responses to available $\mathrm{N}$.

\section{Materials and Methods}

A field experiment was carried out in Uppsala, Sweden, in which the biomass and $\mathrm{N}$ accumulation of crops and the naturally occurring weed flora were assessed in a cropping arrangement including barley and pea sole crops and intercrops grown at two nutrient fertilization levels. ${ }^{15} \mathrm{~N}$ natural abundance and enrichment methods were applied to differentiate between three $\mathrm{N}$ sources (soil mineralization, $\mathrm{N}$ fixation, $\mathrm{N}$ fertilizer) potentially accumulated by the crops and weeds. In addition, various crop canopy traits potentially affecting weed suppression were assessed.

\subsection{Design and Management of the Field Experiment}

The field experiment was set up in Uppsala, Sweden ( $\left.59^{\circ} 50^{\prime} 04.1^{\prime \prime} \mathrm{N} 17^{\circ} 42^{\prime} 09.7^{\prime \prime} \mathrm{E}\right)$ in 2017. The area received a mean monthly precipitation ranging between 10 and $50 \mathrm{~mm}$ and monthly temperatures between 10 and $16^{\circ} \mathrm{C}$ during the growing season (Table A1). The soil is characterized as silt loam. Soil mineral $\mathrm{N}$ content in the topsoil $(0-30 \mathrm{~cm})$ at seeding was $39 \mathrm{~kg} \mathrm{~N} \mathrm{ha}^{-1}$, with $32.5 \mathrm{~kg} \mathrm{~N} \mathrm{ha}^{-1}$ in the form of NO3- and $6.5 \mathrm{~kg} \mathrm{~N} \mathrm{ha}^{-1}$ in the form of $\mathrm{NH}^{+}$.

On 5 May different cultivars (cv.) of barley and pea were sown as sole crops and intercrops, with the intercrops consisting of half (50:50 in a replacement design) the proportion of each sole crop. Sowing was done at a depth of $6 \mathrm{~cm}$ and at $12.5 \mathrm{~cm}$ row distance, with a seed rate of 400 and 90 germinable seeds $\mathrm{m}^{-2}$ for sole spring barley and pea, respectively. The intercrop had half the seed rate of each species in the sole crop, mixed within the same row.

Nitrogen treatment was integrated into the intercropping experiment to include half the plots supplied with $90 \mathrm{~kg} \mathrm{~N} \mathrm{ha}^{-1}$ (YaraBela AXANTM, Yara), while half the plots had no nitrogen applied. All plots were fertilized with $29 \mathrm{~kg} \mathrm{~K} \mathrm{ha}^{-1}$ and $15 \mathrm{~kg} \mathrm{P} \mathrm{ha}^{-1} 26$ days after sowing when barley was in BBCH 13 and pea in BBCH 15 [17], resulting in a split-plot design with nitrogen treatment as a main plot and cultivars as sub-plot with 4 replicates. In total, 176 plots were established, but for this study, 18 plots with spring barley (cv. Tamtam) and pea (cv. Ingrid) were earmarked from a larger experiment. All plots were $2 \mathrm{~m}$ wide and $10 \mathrm{~m}$ long. Plots for ${ }^{15} \mathrm{~N}$-enrichment and natural $\mathrm{N}$ soil content were established within plots with no additional nitrogen as follows (Figure 1). Plots were separated into three parts: $2 \mathrm{~m}$ on one end of the plots was dedicated to the ${ }^{15} \mathrm{~N}$-labelled fertilizer application, whereas $2 \mathrm{~m}$ on the opposite end was used for ${ }^{15} \mathrm{~N}$ natural abundance measurements. The central $6 \mathrm{~m}$ was used for grain yield assessment using a combine harvester. Two microplots for ${ }^{15} \mathrm{~N}$-labelled fertilizer application of size $0.8 \mathrm{~m} \times 0.5 \mathrm{~m}$ (4 rows) were established in the central part of the dedicated area, and the area around was fertilized with the target nitrogen rate $\left(90 \mathrm{~kg} \mathrm{ha}^{-1}\right)$ with ammonium-nitrate. Therefore, the experimental design of the ${ }^{15} \mathrm{~N}$-experiment was a split-plot design with 3 replicates, with the crop as the main plot and $\mathrm{N}$ level as the subplot randomized within the main plots. Grain yield assessment was done in the center $6 \mathrm{~m}$ of the fertilized and unfertilized plots using a combine harvester, resulting in a randomized complete block design with 3 replicates. Pest and disease infestation did not occur in the experiment or only at negligible levels. 


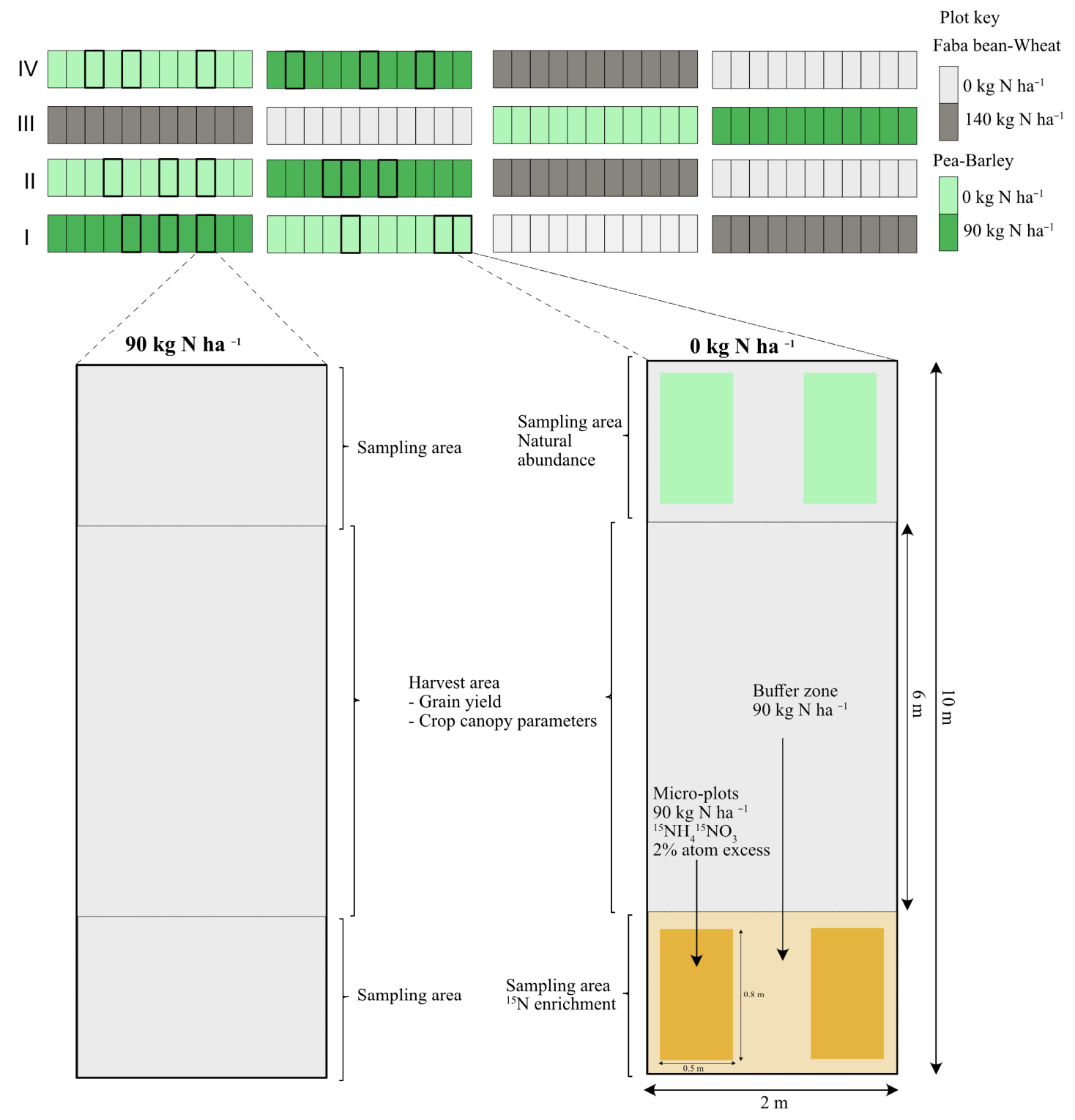

Figure 1. Sketch on the experimental layout for ${ }^{15} \mathrm{~N}$ micro-plots, sampling areas and harvest areas. ${ }^{15} \mathrm{~N}$-enrichment plots were integrated into the experimental plots that did not receive additional $\mathrm{N}$ fertilization $\left(0 \mathrm{~kg} \mathrm{~N}^{-1}\right)$. The plots colored green show pea-barley while grey show faba bean-wheat plots. The light and dark colors denote the different nitrogen treatments.

\section{2. ${ }^{15} \mathrm{~N}$ Solution Preparation and Application in Micro-Plots}

${ }^{15} \mathrm{~N}$-labelled ammonium-nitrate $\left({ }^{15} \mathrm{NH}_{4}{ }^{15} \mathrm{NO}_{3}\right)$ at $5 \%$ atom excess was purchased from Sigma-Aldrich (St. Louis, MO, USA). The amount of ${ }^{15} \mathrm{~N}$-labelled ammonium-nitrate was adjusted with common ammonium-nitrate fertilizer to yield $2 \%{ }^{15} \mathrm{~N}$ atom excess. The required amount for one replicate of ${ }^{15} \mathrm{~N}$-enriched ammonium-nitrate was dissolved in 1.2 $\mathrm{L}$ of deionized water, resulting in $200 \mathrm{~mL}$ solution for each micro-plot. The adjusted fertilizer ammonium-nitrate was spread in the micro-plots, and the solution was applied using a syringe. To achieve a homogeneous distribution of the solution, each of the four crop rows in the micro-plots was applied separately with $50 \mathrm{~mL}$ of solution.

\subsection{Biomass and Grain Yield Assessment}

Biomass sampling was performed at flowering (barley: $\mathrm{BBCH} 61$; pea: $\mathrm{BBCH} 67$ ) and maturity in both the ${ }^{15} \mathrm{~N}$ micro-plots and the large harvest plots. At each periodic sampling, 
two central rows of one micro-plot and N-level were cut above the soil surface. After the number of plants was counted the samples were dried at $70{ }^{\circ} \mathrm{C}$ for $72 \mathrm{~h}$ to measure dry biomass.

Grain yield was measured by harvesting the center $6 \mathrm{~m}$ of the plots with a combine harvester. Grain moisture content was measured by weighing subsamples before and after drying for $48 \mathrm{~h}$ at $70{ }^{\circ} \mathrm{C}$. Grain samples were cleaned to account for impurities. The presented grain yield was corrected for moisture and impurities.

The crop traits canopy height and leaf area index (LAI) and aboveground biomass were measured in the plots dedicated to grain yield assessment. Crop and weed biomass in plots were assessed by harvesting 2 times $0.25 \mathrm{~m}^{2}$ at the soil surface in the sampling areas at either end of each plot, separating the samples into the different species, counting and oven-dry them for $48 \mathrm{~h}$ at $70{ }^{\circ} \mathrm{C}$. Canopy height was measured shortly before flowering by taking vertical measurements from the soil surface to the top of the highest plant per species from three positions within each plot. These measured canopy height values were used to calculate the weighted means and maximum canopy heights. The LAI calculation of the crops was based on individual plant measurements using the leaf disc method [18]. Five plants of each crop species were randomly selected in each plot. Leaves were separated from shoots, and 10 leaf discs of diameter $6 \mathrm{~mm}$ and $8 \mathrm{~mm}$ were punched out of barley and pea leaves, respectively. Leaf discs were taken from leaves of different age, and from different positions on the plant and leaf blades. Leaf discs and leaf biomass were dried at $70{ }^{\circ} \mathrm{C}$ for $48 \mathrm{~h}$. On the basis of the specific leaf area and leaf biomass, the total leaf area per plant was calculated. The LAI was calculated by multiplying leaf area per crop plant by crop plant density in the known plot area.

\subsection{Isotope Analysis}

Isotope analysis was performed by the SLU Stable Isotope Laboratory (SSIL) at the Department of Forest Ecology and Management at the Swedish University of Agricultural Sciences (SLU), Umeå. The dried biomass samples were milled with a rotor mill to particle size $<0.5 \mathrm{~mm}$. Dry mass was defined by oven drying at $70{ }^{\circ} \mathrm{C}$ for at least $18 \mathrm{~h}$. Nitrogen mass fractions and isotope ratios were determined using an elemental analyzer (Flash EA 2000, Thermo Fisher Scientific, Bremen, Germany) coupled to an isotope ratio mass spectrometer (DeltaV, Thermo Fisher Scientific, Bremen, Germany) (EAIRMS) [19]. Wheat and maize flours calibrated against several reference standards were used as working standards.

\subsection{Calculations}

The calculation of the amount of $\mathrm{N}$ available to weeds was based on the total accumulated $\mathrm{N}$ in crop and weed biomass in unfertilized barley plots as reference, assuming it a realistic integrated measure of total plant available $\mathrm{N}$ during the growing season. Since not all of the $90 \mathrm{~kg} \mathrm{~N} \mathrm{ha}^{-1}$ supplied as fertilizer will be available to crops and weeds due to, e.g., leaching, the maximum observed recovered fertilizer $\mathrm{N}$ ( $40 \mathrm{~kg} \mathrm{ha}^{-1}$ in sole-crop barley) was added to the reference amount to estimate $\mathrm{N}$ available to weeds in the fertilized plots. The addition of the observed recovered fertilizer $\mathrm{N}$ was seen as a more realistic measure than the supplied $90 \mathrm{~kg} \mathrm{~N} \mathrm{ha}^{-1}$, as the fertilizer $\mathrm{N}$ recovery was on average only at $29 \%$. The amount of $\mathrm{N}$ available to weeds in each plot was calculated by subtracting the amount of $\mathrm{N}$ derived from soil and fertilizer in crop plants from the respective reference plot in each block. This calculation was done for both sampling time points, crop flowering and maturity.

In the unfertilized plots, the natural abundance technique was used to assess the proportion of nitrogen derived from fixation ( $N d f a \%)$, following the equation [20]

$$
N d f a(\%)=\frac{\delta^{15} N_{\text {barley }}-\delta^{15} N_{\text {pea }}}{\delta^{15} N_{\text {barley }}-B} \times 100
$$


$\delta^{15} \mathrm{~N}$ gives the abundance of ${ }^{15} \mathrm{~N}$ in parts per thousand relative to air and $\mathrm{B}$ is a measure of fractionation in the plant during $\mathrm{N}_{2}$ fixation. For analysis, a B value of $-0.7 \%$ was used [21].

The atom $\%{ }^{15} \mathrm{~N}$ of the plant material was converted into delta notation according to the following formula [20]:

$$
\delta^{15} N(\%)=\frac{\text { atom } \%{ }^{15} N_{\text {sample }}-\text { atom } \%{ }^{15} N_{\text {standard }}}{\text { atom } \%{ }^{15} N_{\text {standard }}} \times 1000
$$

Atom $\%{ }^{15} \mathrm{~N}$ of air $(0.3663)$ was used as standard.

In the fertilized treatments the isotope dilution equations were applied to estimate the proportions of nitrogen derived from fixation $(\mathrm{Ndfa} \%)$, from the soil $(\mathrm{Ndfs} \%)$ and from fertilizer (Ndff\%) [22]:

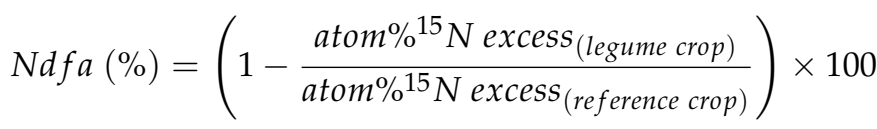

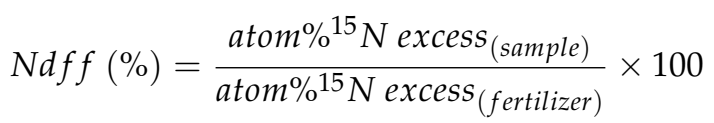

$$
\begin{aligned}
& N d f s(\%)=100-N d f a(\%)-N d f f(\%)
\end{aligned}
$$

Sole-cropped barley was used as reference crop for both the natural abundance and isotope dilution, to be able to compare it to the most relevant literature to our study. Atom $\%{ }^{15} \mathrm{~N}$ excess of plant material was calculated by subtracting the ${ }^{15} \mathrm{~N}$ natural abundance in unfertilized barley $(0.3678$ atom $\%)$ at the respective sampling dates from the other treatments.

\subsection{Statistical Analysis}

Data were subjected to an analysis of variance at $\alpha=0.05$ using linear mixed models including random effects for blocks and, where appropriate given the experimental design (data derived from ${ }^{15} \mathrm{~N}$-experiment), a random effect for the main plot. Normal distribution and heterogeneity of variances were checked visually by inspection of Q-Q plots and residual plots. Where these assumptions were not met, data were $\ln$-transformed. Any transformations done on the data were indicated in the corresponding figure and table legends. In such cases, back-transformed means estimating medians of the original sample and standard errors are presented, obtained via the delta method suggested by [23]. Fixed effects included in the models depended on the respective analysis and included sampling time, crop, $\mathrm{N}$-level and species. The effects included in each analysis can be derived from the respective tables in the results or Appendix A (Tables 1 and 2, Tables A2 and A6). To test on pairwise differences following analysis of variance, Tukey HSD was calculated $(\alpha=0.05)$. Analyses were performed using R 3.6.1 [24] and the packages 'lme4' [25], 'ImerTest' [26] and 'emmeans' [27]. Marginal and conditional $\mathrm{R}^{2}$ of linear regressions were calculated according to [28] using the package 'performance' [29]. The method and package used allows to calculate $R^{2}$ for linear mixed models, where the marginal $R^{2}$ gives the variance that is explained by the fixed effects only, and the conditional $R^{2}$ gives the variance explained by both fixed and random effects. 
Table 1. $p$-values following analysis of variance and sums of squares (SS) of total accumulated plot biomass (crops + weeds) measured in $\mathrm{g} \mathrm{m}^{-2}$ and proportional crop and weed biomass to the total biomass in dependency of sampling time, crop and N-level. $p$-values smaller 0.05 are marked in bold. $n=3$.

\begin{tabular}{ccccc}
\hline Factor & $\begin{array}{c}\text { Total Accumulated } \\
\text { Crop + Weed Biomass }\end{array}$ & SS & $\begin{array}{c}\text { Proportion of Crop and } \\
\text { Weed to the Total Biomass }\end{array}$ & $\begin{array}{c}\text { SS } \\
\text { Sampling time }\end{array}$ \\
Crop & $<\mathbf{0 . 0 0 0 1}$ & 365,138 & 0.18 & 0.0054 \\
N-level & 0.52 & 13,489 & $\mathbf{0 . 0 4}$ & 0.0345 \\
Sampling time $\times$ Crop & 0.76 & 864 & 0.01 & 0.0240 \\
Sampling time $\times$ N-level & 0.36 & 18,901 & 0.16 & 0.0115 \\
Crop $\times$ N-level & 0.87 & 255 & 0.03 & 0.0147 \\
Sampling time $\times$ crop $\times$ N-level & 0.70 & 6454 & 0.43 & 0.0050 \\
\hline
\end{tabular}

Table 2. Effect of crops, N-levels, and their interaction on crop traits, $\mathrm{N}$ availability to weeds and $\mathrm{N}$ accumulation from different sources, assessed in original plots (leaf area index LAI $\left(\mathrm{m}^{2} \mathrm{~m}^{-2}\right)$, weighted and max canopy height $\left.(\mathrm{cm})\right)$ and ${ }^{15} \mathrm{~N}$ micro-plots (crop biomass $\left(\mathrm{g} \mathrm{m}^{-2}\right.$ ) and $\mathrm{N}$ available to weeds $\left(\mathrm{g} \mathrm{m}^{-2}\right)$ ) at crop flowering and maturity. Numbers are $p$-values following analysis of variance as well as the sums of squares (SS). $p$-values smaller 0.05 are marked in bold. $n=3$.

\begin{tabular}{ccccccc}
\hline Plant Characteristic & \multicolumn{5}{c}{ Treatment } \\
\hline & Crop & SS & N-Level & SS & Crop $\times$ N-level & SS \\
\hline LAI & $<\mathbf{0 . 0 0 1}$ & 4.7 & $\mathbf{0 . 0 2 3}$ & 0.7 & 0.213 & 0.4 \\
Weighted canopy height & 0.118 & 27.1 & 0.325 & 5.6 & 0.341 & 12.4 \\
Max canopy height & 0.269 & 10.3 & 0.185 & 7.0 & 0.214 & 0.359 \\
Crop biomass & 0.358 & 16,761 & 0.965 & 13.3 & 0.476 \\
N available to weeds at crop flowering & 0.106 & 11.6 & $\mathbf{0 . 0 0 7}$ & 44.8 & 0.056 & 7.5 \\
N available to weeds at crop maturity & 0.294 & 1.3 & $\mathbf{< 0 . 0 0 1}$ & 118.9 & 0.280 \\
\hline
\end{tabular}

\section{Results}

\subsection{The Cropping Arrangements Provided a Gradient of Differential Soil N Availabilities to the Weeds}

The crop biomass in the micro-plots used for the ${ }^{15} \mathrm{~N}$ analyses was significantly correlated with the biomasses of the larger plots used for the crop and weed biomass and $\mathrm{N}$ assessments (Figure A1). The total accumulated biomass (crop + weed) was similar in all cropping arrangements but varied between crop flowering and maturity, while the proportional contribution of crop and weed biomass to the total biomass was affected by the N-level (Table 1). The proportional weed biomass was higher in the crops receiving additional $\mathrm{N}$ compared to unfertilized crops only at crop maturity (16\% vs. $7 \%$ ) but not at flowering (10\% vs. $9 \%)$.

Total crop biomass at flowering was similar for all crops and was unaffected by fertilization (Table 2). Crop LAI was significantly lower in sole-crop pea than in solecrop barley and the intercrop and was increased by additional $\mathrm{N}$ application (Table 2, Figure $\mathrm{A} 2 \mathrm{a}, \mathrm{b})$. The $\mathrm{N}$ availability to weeds, i.e., soil and fertilizer $\mathrm{N}$ that was not taken up by the crops, gradually increased along the series of cropping arrangements (Figure A2d). This gradient was significant only at crop maturity and at $\alpha=0.1$ (crop $\times$ N-level interaction $p=0.056$; Table 2). At crop flowering, $\mathrm{N}$ availability to weeds was mainly determined by $\mathrm{N}$ fertilization and not the crop (Figure A2c).

\subsection{Total Weed Biomass Is More Strongly Related to N Availability to Weeds Than to Crop Canopy Traits (H1)}

Weed biomass was negatively correlated to crop biomass (Figure 2a), and weeds had accumulated more biomass at crop maturity compared to flowering. Furthermore, weed biomass was positively correlated to the amount of soil $\mathrm{N}$ available to weeds, with a more pronounced effect at crop maturity compared to flowering (Figure 2b). The models for 
crop biomass and $\mathrm{N}$ available to weeds explained large proportions of the observed weed biomass (65\% and $75 \%$ respectively, conditional $\mathrm{R}^{2}$ shown in Figure 2 ). The amount of $\mathrm{N}$ available to weeds alone explained $44 \%$ of weed biomass accumulation, whilst crop biomass alone explained 38\% (marginal $\mathrm{R}^{2}$ ).
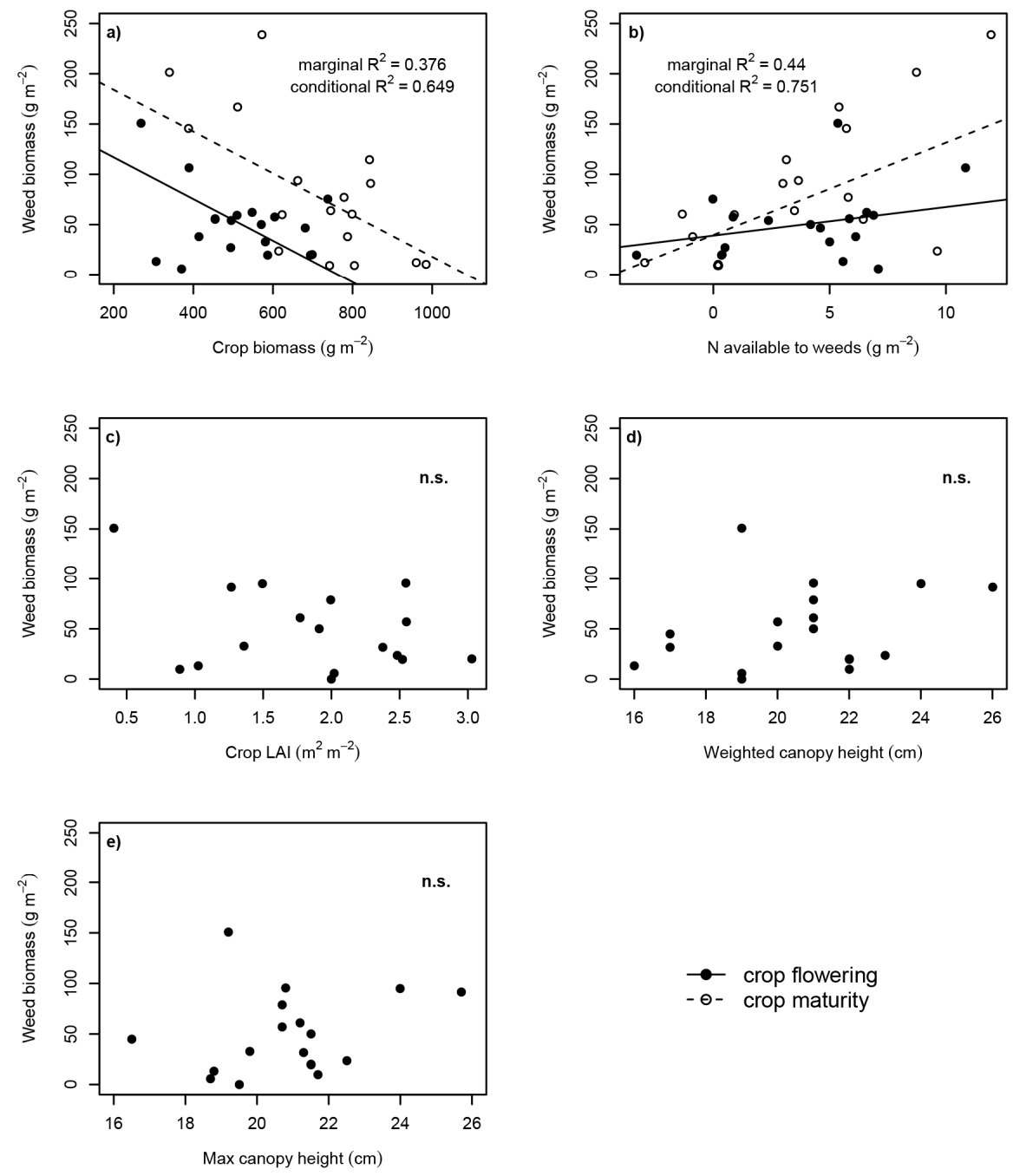

$\rightarrow$ crop flowering
$-\Theta-$ crop maturity

Figure 2. Relationships between weed biomass accumulation and characteristics of cropping arrangements at crop flowering and maturity. (a) Crop biomass ( $p=0.004$; sampling time $p=0.006$; Crop biomass $\times$ sampling time $p=0.104)$ and $(\mathbf{b}) \mathrm{N}$ available to weeds $(p=0.009$; sampling time $p=0.969$; $\mathrm{N}_{\text {available to weeds }} \times$ sampling time $p=0.003$ ), both measured in the ${ }^{15} \mathrm{~N}$ micro-plots, (c) crop LAI $(p=0.185)$, (d) weighted canopy height $(p=0.317)$ and (e) maximum canopy height $(p=0.387)$, all measured in the large harvest plots. Marginal $\mathrm{R}^{2}$ is the variance explained by the fixed effects; conditional $\mathrm{R}^{2}$ is the variance explained by both fixed and random effects [28].

Although the crop LAI differed significantly between the cropping arrangements, there was no significant relationship to accumulated weed biomass (Figure 2c), neither was it for crop canopy height (Figure 2d,e).

\subsection{The HNR Species Accumulated More Biomass and N Than the RNR Species (H2)}

Biomass and $\mathrm{N}$ accumulation differed significantly between weed groups $(p<0.0001$, Table A2). Averaged across the experiment, C. album accumulated more biomass and $\mathrm{N}$ per area than Galeopsis spp. (Table 3). 
Table 3. Biomass, $\mathrm{N}$ accumulation and $\mathrm{N}$ derived from fertilizer (Ndff) of Chenopodium album, Galeopsis spp. and the remaining weeds. Different letters indicate significant differences between the species following pairwise comparison (Tukey, $\alpha=0.05$ ) based on ln-transformed data, except for Ndff (\%).Values presented are estimated medians in case of back-transformed data and estimated means (for Ndff (\%)). Standard errors are given in parenthesis. Back-transformed means (estimating medians) and standard errors were obtained by back-transformation via the delta method. The original estimates based on ln-transformed data are presented in Table A3.

\begin{tabular}{cccc}
\hline & C. album & Galeopsis spp. & Remaining Weeds \\
\hline Biomass $\left(\mathrm{g} \mathrm{m}^{-2}\right)$ & $44.8(13.70)^{\mathrm{b}}$ & $5.9(1.76)^{\mathrm{a}}$ & $4.9(1.27)^{\mathrm{a}}$ \\
Accumulated N $\left(\mathrm{g} \mathrm{m}^{-2}\right)$ & $1.14(0.280)^{\mathrm{b}}$ & $0.13(0.035)^{\mathrm{a}}$ & $0.13(0.029)^{\mathrm{a}}$ \\
Ndff $\left(\mathrm{g} \mathrm{m}^{-2}\right)$ & $0.73(0.213)^{\mathrm{b}}$ & $0.08(0.030)^{\mathrm{a}}$ & $0.06(0.018)^{\mathrm{a}}$ \\
Ndff $(\%)$ & $44.0(3.50)^{\mathrm{a}}$ & $53.5(3.58)^{\mathrm{b}}$ & $41.6(3.56)^{\mathrm{a}}$ \\
\hline
\end{tabular}

Besides the general effects of, e.g., crop, N-level or sampling time on weeds, we observed species-specific differences of weed biomass and $\mathrm{N}$ accumulation in relation to $\mathrm{N}$ level and crop (Table A2). Additional $\mathrm{N}$ application increased biomass and $\mathrm{N}$ accumulation of C. album, while it had no effects on Galeopsis spp. (Figure 3a,c). In sole-crop barley and pea (not the intercrop), C. album accumulated more biomass and $\mathrm{N}$ than Galeopsis spp. (Figure 3b,d).
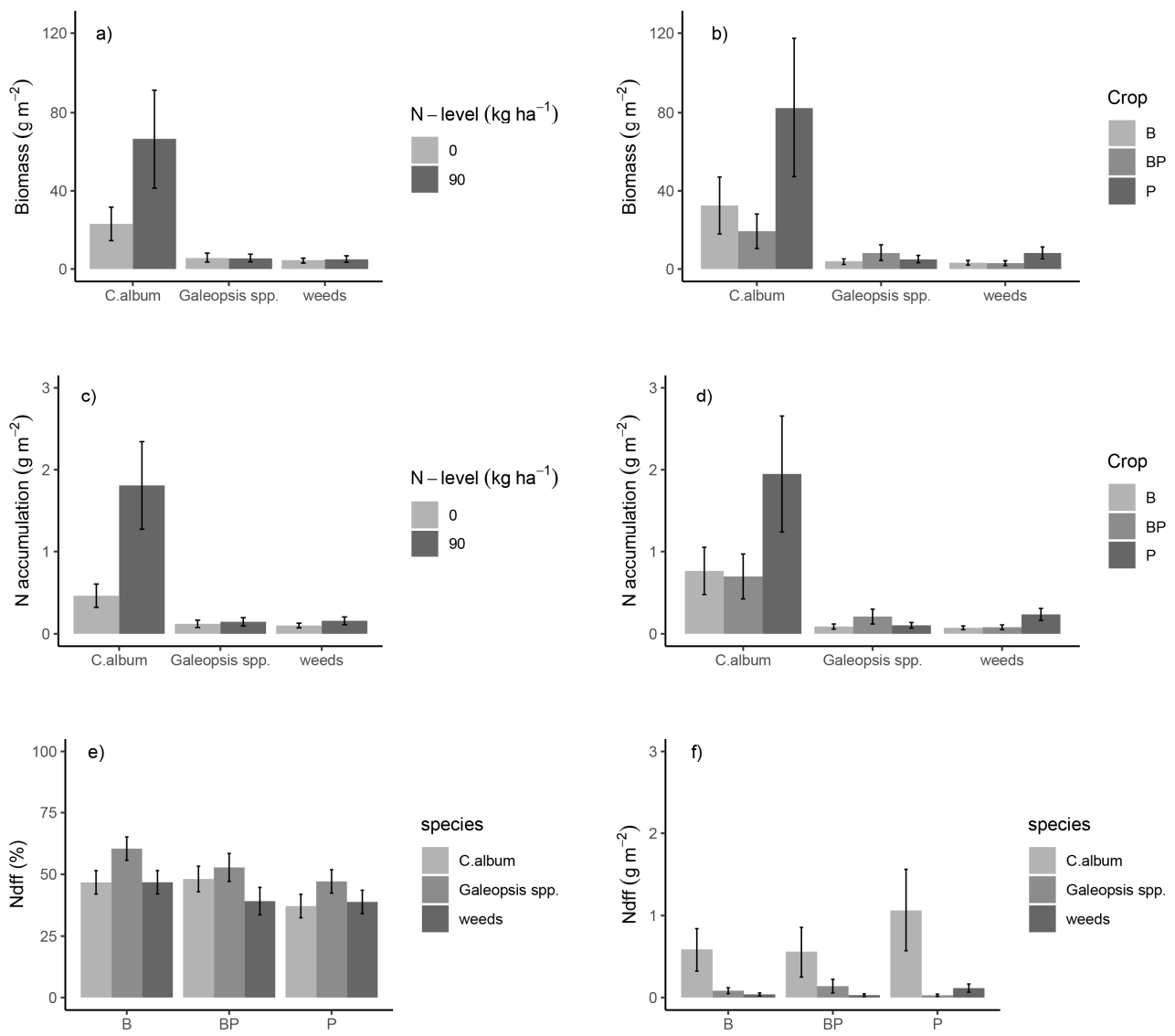

Figure 3. Weed species biomass $(\mathbf{a}, \mathbf{b}), \mathrm{N}$ accumulation $(\mathbf{c}, \mathbf{d})$, relative amount of $\mathrm{N}$ derived from fertilizer (Ndff) (e) and absolute Ndfs (f) for different weed species or crops (B-barley, P-pea, $\mathrm{BP}$-barley-pea mixture) and separated for two different $\mathrm{N}$ levels. Values presented in (a-d) and (f) are back-transformed following ln-transformation and therefore represent medians rather than means. Error bars represent (back-transformed) standard errors of estimates. Back-transformation was performed with the delta method. Results are averaged over the experimental factors sampling time and N-level (d,e) or crop (a,c) and sampling time (e). 
C. album took up more $\mathrm{N}$ derived from fertilizer (Ndff) than Galeopsis spp. but covered lower proportions of its $\mathrm{N}$ uptake by fertilizer $\mathrm{N}$ (Table 3).

Fertilizer $\mathrm{N}$ accumulation of the weed groups was also influenced by the crop (Table A2). C. album took up more fertilizer $\mathrm{N}$ in sole-crop pea and barley compared to Galeopsis spp. but similar amounts in the intercrop (Figure 3f). The results for $\mathrm{N}$ derived from soil (Ndfs) were comparable to those of Ndff (Table A4).

Compared to the crops, C. album acquired similar amounts of fertilizer $\mathrm{N}$ as barley and pea irrespectively of the crop composition, but barley accumulated more Ndfs than C. album (Table A4).

The weeds other than the ones studied here showed similar patterns (Figure 3a-d) as Galeopsis spp. and took up similar amounts of Ndff, but covered lower proportions of their $\mathrm{N}$ uptake by Ndff (Table 3). In general, all weed groups covered larger proportions of their $\mathrm{N}$ uptake from fertilizer $\mathrm{N}$ in sole-crop barley than in sole-crop pea, with the intercrop ranging in between (Figure 3e, Table A2), and the proportion reduced from flowering (51\%) to maturity $(42 \%)$.

\subsection{Increasing N Availability Favoured Only the HNR Weed Species (H3)}

The responses of biomass and $\mathrm{N}$ accumulation to increasing $\mathrm{N}$ availability varied significantly between the weed groups and were similar at crop flowering and maturity. Galeopsis spp. biomass and $\mathrm{N}$ accumulation were unaffected by $\mathrm{N}$ availability, whereas the biomass and $\mathrm{N}$ accumulation of $\mathrm{C}$. album and the remaining weeds significantly increased with increasing $\mathrm{N}$ availability (Figure 4; Table 4).
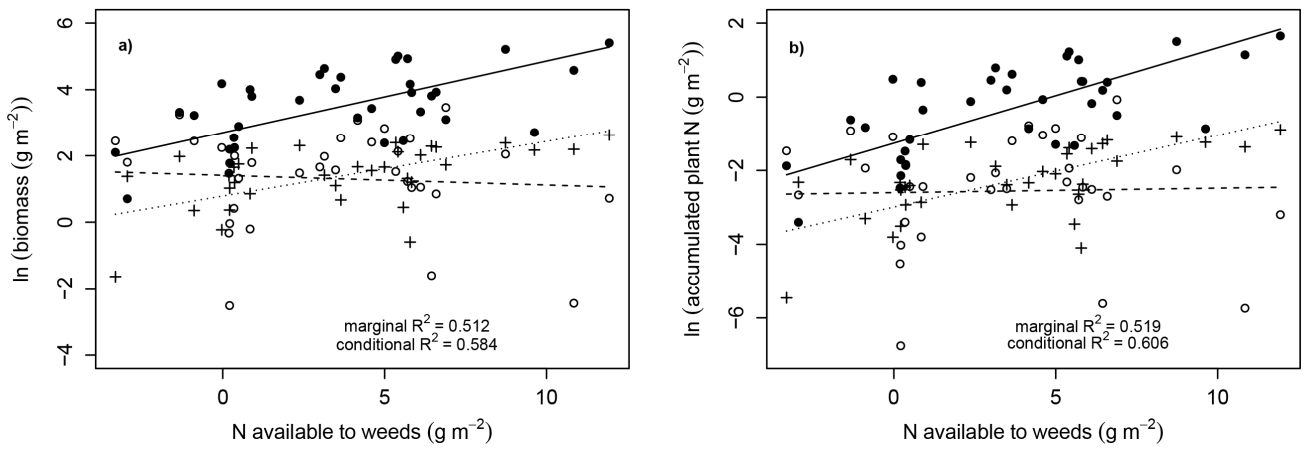

$$
\begin{array}{ll}
-\bullet & \text { C.album } \\
-0 . & \text { Galeopsis spp. } \\
\cdots+\cdot & \text { remaining weeds }
\end{array}
$$

Figure 4. The biomass (a) ( $\mathrm{N}$ availability $p=0.001$, species $p=0.001, \mathrm{~N}$ availability $\times$ species $p=0.002$ ) and $\mathrm{N}$ accumulation $(\mathbf{b})(\mathrm{N}$ availability $p=0.001$, species $p=0.001, \mathrm{~N}$ availability $\times$ species $p=0.002$ ) of different weed species or groups of weeds as functions of the $\mathrm{N}$ availability. The regressions are averaged over the sampling times due to non-significance of this factor. Marginal $\mathrm{R}^{2}$ : variance explained by the fixed effects only; conditional $\mathrm{R}^{2}$ : variance explained by fixed and random effects. Negative values are due to the calculation using unfertilized sole-crop barley plots as reference for the integrated seasonal $\mathrm{N}$ availability. In the respective plots more soil/fertilizer $\mathrm{N}$ was taken up by the crop than in sole-crop barley. 
Table 4. Slope estimates and 95\% confidence intervals for the regressions of weed species biomass and accumulated $\mathrm{N}$ over $\mathrm{N}$ availability presented in Figure 4. Different letters indicate significant different slopes following a pairwise comparison (Tukey, $\alpha=0.05$ ).

\begin{tabular}{|c|c|c|c|c|}
\hline \multirow{2}{*}{ Species } & \multicolumn{2}{|c|}{ Biomass ( $\mathrm{g} \mathrm{m}^{-2}$ ) } & \multicolumn{2}{|c|}{ Accumulated Plant $\mathrm{N}\left(\mathrm{g} \mathrm{m}^{-2}\right)$} \\
\hline & Slope & $95 \%$ CI & Slope & $95 \%$ CI \\
\hline C. album & $0.216^{\mathrm{a}}$ & $\begin{array}{l}0.109 \\
0.322\end{array}$ & $0.259^{a}$ & $\begin{array}{l}0.156 ; \\
0.363\end{array}$ \\
\hline Galeopsis spp. & $-0.029^{b}$ & $\begin{array}{c}-0.139 \\
0.081\end{array}$ & $0.012^{b}$ & $\begin{array}{c}-0.095 \\
0.119\end{array}$ \\
\hline Remaining weeds & $0.165^{\mathrm{a}}$ & $\begin{array}{l}0.059 \\
0.271\end{array}$ & $0.195^{\mathrm{a}}$ & $\begin{array}{l}0.092 \\
0.299\end{array}$ \\
\hline
\end{tabular}

\section{Discussion}

The system of unfertilized and fertilized intercrops and sole crops established a biologically induced $\mathrm{N}$ gradient in the field. Weed biomass and $\mathrm{N}$ accumulation along the $\mathrm{N}$ gradient was found to be dependent on the weed species considered. The two weed species used here should represent two groups of weeds, i.e., those with high $\mathrm{N}$ responsiveness (HNR) and reduced $\mathrm{N}$ responsiveness (RNR), although further research needs to verify to what extent those two species can be considered representative for the two groups of weed species addressed here. Only the highly $\mathrm{N}$ responsive species (HNR, here C. album) clearly benefitted from enhanced $\mathrm{N}$ availability in terms of increasing biomass and $\mathrm{N}$ accumulation along the gradient. The species with reduced responsiveness to $\mathrm{N}$ (RNR, here Galeopsis spp.) did not respond to increased $\mathrm{N}$ availability in terms of biomass and $\mathrm{N}$ accumulation. Additional $\mathrm{N}$ supply favored only the HNR species, but neither the RNR species nor the crop. Barley has a higher demand for $\mathrm{N}$ and a faster and deeper root growth than pea, allowing it to rapidly explore $\mathrm{N}$ resources in the soil [30]. Therefore, the soil $\mathrm{N}$ potentially available to weeds can be expected to be lower under sole crop barley than the intercrop, while higher amounts of soil $\mathrm{N}$ can be expected to be available to weeds under sole crop pea [31]. The differences might be even more pronounced following additional $\mathrm{N}$ supply because the $\mathrm{N}$ uptake of pea does not increase with increasing $\mathrm{N}$ levels to the same extent as the demand of barley [30]. As expected, this gradient of $\mathrm{N}$ availability was reflected in our study system. The effect of $\mathrm{N}$ fertilization was most pronounced in our study, however with a marginal significance of the crop and $\mathrm{N}$-level interaction at crop maturity. Given the usually high variation of $\mathrm{N}$ availability in a field, as was also observed in our data, it would have required more replicates to support a statistically, highly significant gradient at all crop stages.

Both crops achieved grain yields representative for the region (sole-crop barley $6.1 \mathrm{tha}^{-1}$ and sole-crop pea $1.9 \mathrm{t} \mathrm{ha}^{-1}$ ). Grain yields of both barley and pea were influenced only by the cultivation as sole-crop or intercrop. $\mathrm{N}$ fertilization did not increase crop biomass accumulation at crop flowering (Table 2) nor grain yield (Table A6). Grain yields of both crop components were significantly lower in the intercrop compared to the respective sole crops with a stronger reduction in yield of the pea component. Barley grain yield was reduced to $4.3 \mathrm{tha}^{-1}$ and that of pea to $0.6 \mathrm{t} \mathrm{ha}^{-1}$. The stronger reduction of pea grain yield in the intercrop reflects the stronger competitiveness of barley and is commonly observed in many cereal-legume mixtures [6].

Contrary to the commonly observed effect of intercropping and $\mathrm{N}$ availability on the $\mathrm{N}_{2}$ fixation in pea, the proportion of $\mathrm{N}$ derived from fixation in our study was not influenced by intercropping nor by the $\mathrm{N}$ level and in average $38 \%[6,32,33]$ (Table A6). $\mathrm{N}_{2}$ fixation is frequently limited by, and negatively correlated to, the nitrate content in the soil [34], but the limitation or inhibition of $\mathrm{N}_{2}$ fixation after fertilization, especially at early stages, only occurs temporarily as the crop later recovers its optimal $\mathrm{N}_{2}$ fixation level [35]. The high soil $\mathrm{N}$ content in our study could indicate that the soil $\mathrm{N}$ was sufficient to have an inhibitory effect on $\mathrm{N}_{2}$ fixation, and the additional $\mathrm{N}$ fertilization had no further effect. This high soil $\mathrm{N}$ and inhibitory effect could also explain the comparably low level of average 
$\mathrm{N}_{2}$ fixation for pea in the intercrop (Table A6). Consequently, crop-weed interaction was mainly influenced by the amount of soil and fertilizer $\mathrm{N}$ available to weeds, which resulted in high $\mathrm{N}$ accumulation and biomass produced, especially by HNR (C. album) in plots where fertilizer was applied.

\subsection{Nitrogen Fertilization Increased Weed Biomass in Relation to Crop Biomass}

It cannot be concluded from the results that the system was limited by $\mathrm{N}$; therefore, assumptions about the strength of competitiveness between crops and weeds for $\mathrm{N}$ cannot be made. The limited amount of data-points per crop ( 3 replicates $\times 2$ N-levels) does not allow to assess crop yield-weed biomass relationships, but the lack of crop yield response to $\mathrm{N}$ fertilization in combination with higher weed biomass at higher $\mathrm{N}$-levels suggests that the effect of weeds on crop yields was rather small, at least within the range of observed weed biomasses. However, the proportional weed biomass was higher in the fertilized plots, and this shift became significant after crop flowering, when crops did not take up large amounts of $\mathrm{N}$. This shift was also displayed by the generally higher weed biomass accumulation per crop biomass at crop maturity. Late emerging cohorts of weed seeds, as both reported for C. album and Galeopsis spp. [36], could have contributed to the increasing weed biomass at the later crop growth stage. The stronger response of weed biomass accumulation to available $\mathrm{N}$ at crop maturity compared to flowering indicates a more efficient use of the available $\mathrm{N}$ resources of weeds later in the season. There was no clear evidence for aboveground competition between crops and weeds for light (assessed crop canopy parameters and weed biomass were unrelated), and the aboveground weed biomass was negatively correlated to crop biomass. However, evidence abounds that belowground interactions, which were not in the focus of this study, are the driving factors for crop-weed interactions in barley [37].

\subsection{Additional N Supply Clearly Affected the Biomass Distribution between Crops and Weeds}

Contrary to the initial part of our first hypothesis, weed biomass was uncorrelated with leaf area index and canopy height of the crops, but instead strongly correlated to crop biomass and even more to $\mathrm{N}$ availability. Thus, the positive effect of increased $\mathrm{N}$ availability on weed biomass accumulation was clearly stronger than the weed suppression effects of the crop canopy in our study, supporting the second part of our first hypothesis. When considering the weed and crops combined, the similar amount of biomass produced, and combined soil and fertilizer $\mathrm{N}$ accumulation of crop and weeds at crop flowering and maturity in both fertilized and unfertilized plots might indicate either $\mathrm{N}$ limitation, or sufficient $\mathrm{N}$ availability, because soil $\mathrm{N}$ availability was sufficient to otherwise result in decreased biomass accumulation in the unfertilized plots. On the one hand, the soil mineral $\mathrm{N}$ content of $39 \mathrm{~kg} \mathrm{~N} \mathrm{ha}^{-1}$ at seeding in the top $30 \mathrm{~cm}$ was high. The total accumulated soil $\mathrm{N}$ in the unfertilized barley sole crop of around $11 \mathrm{~g} \mathrm{~m}^{-2}$ indicates that at least $110 \mathrm{~kg} \mathrm{~N} \mathrm{ha}^{-1}$ was provided by soil $\mathrm{N}$ mineralization, which can be considered above average compared to other sites in Sweden [38]. On the other hand, nitrogen limitation in the crop can also be the result of $\mathrm{N}$ uptake limitation. For example, low soil temperatures reduce the high-affinity nitrogen influx into roots, reducing root growth and branching angle of lateral roots, which is indicative of reduced soil volume coverage [39,40]. Soil temperatures of $<10^{\circ} \mathrm{C}$ within the first 30 days after sowing in our experiment could have hampered root growth and nitrogen uptake, which would also explain the low fertilizer recovery rates of $29 \%$ on average in our system [41]. This recovery rate is indicative of a suboptimal fertilization regime, as commonly observed fertilizer recovery rates in spring barley are between 37 and 65\% [32,40,42].

Irrespective of the fertilizer recovery or strength of $\mathrm{N}$ limitation in our system, the additional $\mathrm{N}$ supply in the high-fertilizer plots caused a shift in biomass distribution among crops and weeds, which further provided a gradient in $\mathrm{N}$ availability to weeds causing differences in the weed group's growth. In the case that the remaining fertilizer N was not lost due to, e.g., leaching or immobilized by soil microorganisms, the $\mathrm{N}$ amount available to 
weeds was higher compared to common conditions that could have decreased competition for N. Competition is usually reduced as resource availability increases [43]. At limited $\mathrm{N}$ availability, increased competition altered the biomass distribution among the species. If $\mathrm{N}$ was not assumed to be most growth-limiting, the established gradient was still effective enough to cause shifts in species dominance even under low $\mathrm{N}$ conditions.

\subsection{Differential Responses of Weed Groups to the Nitrogen Gradient}

The HNR species, here C. album, benefitted from increased $\mathrm{N}$ availability as demonstrated by the increased accumulation of both biomass and N, while the RNR species, here Galeopsis spp., did not respond to the increase in available N. These observations are generally in support of our second and third hypotheses. There can be different underlying reasons for that. Varying $\mathrm{N}$ responsiveness at species level can cause distinct responses to $\mathrm{N}$ gradients. However, as both species groups are nitrophilic, Galeopsis spp. could also be expected to respond with increasing growth to enhanced $\mathrm{N}$ availability, at least for a certain stretch of the $\mathrm{N}$ availability gradient, as was shown elsewhere under controlled conditions [13]. The lack of $\mathrm{N}$ response for one of the weeds indicates that competition between them was important, and it appears that Galeopsis spp. was suppressed by C. album. The higher capacity of C. album in accumulating available soil $\mathrm{N}$ compared to Galeopsis spp., as well as its stronger response in root growth to increasing N levels [13], suggests an increasing competitive advantage of $C$. album for $\mathrm{N}$ acquisition at increasing $\mathrm{N}$ availability, as rapid growth of root length is a pre-requisite for belowground competition in terms of pre-empting nutrient supplies [44]. Furthermore, the competitive strength of a given species in a community is strongly related to its size, as competition for resources between plants is usually partially size asymmetric providing the taller species with a competitive advantage, which is especially true for light pre-emption. Increased shoot growth leading to size asymmetry in competition for light requires increased nutrient capture to support shoot growth, which makes shoot and root competition interacting $[45,46]$. The aboveground biomass of C. album was several times higher than the biomass of Galeopsis spp., equipping it with an advantage from the beginning. However, the biomass alone cannot explain the competitive advantage of C. album over Galeopsis spp. in terms of growth response and $\mathrm{N}$ acquisition at increasing $\mathrm{N}$ availability, which ultimately led to the suppression of this weed group. The remaining weeds together had comparably low biomass as Galeopsis spp., but they responded similarly as C. album with increased biomass and $\mathrm{N}$ accumulation at increasing $\mathrm{N}$ availability.

Even if the relative importance of belowground competition decreases with increasing nutrient availability [45], the results suggest that the ability to acquire increasing amounts of $\mathrm{N}$ at increasing $\mathrm{N}$ availability played a significant role in weed growth. In comparison to the two crop species, the HNR species also benefitted more from additional $\mathrm{N}$ supply, as demonstrated by increased biomass accumulation along increasing $\mathrm{N}$ availability, while both barley and pea had similar biomass accumulation at both $\mathrm{N}$ levels. Consequently, the HNR species was a stronger competitor for fertilizer $\mathrm{N}$ in all crops compared to the RNR species (supporting our second hypothesis) and the crops, which was most evident in sole crop pea, where it accumulated similar fertilizer- $\mathrm{N}$ amounts as pea. This finding is in line with results from experiments under controlled conditions, where the competitiveness of a highly N-responsive weed with wheat increased with increasing $\mathrm{N}$ levels, while the competitive ability of species with reduced responsiveness was unaffected [47].

With decreasing $\mathrm{N}$ availability along the series of cropping arrangements, weeds covered lower proportions of their $\mathrm{N}$ uptake from fertilizer $\mathrm{N}$, and consequently, more from the soil. In addition, the more competitive HNR species covered a lower proportion of its $\mathrm{N}$ uptake from fertilizer $\mathrm{N}$ compared to the RNR species. This pattern probably reflects a greater availability of the fertilizer $\mathrm{N}$ early in the growing season when the fertilizer was applied, along with a greater capacity of the weeds (especially HNR species) to rapidly take up much of the fertilizer $\mathrm{N}$ before the crop was capable of accumulating significant amounts of it. The aforementioned stronger root growth response to increasing N-levels of 
this species could also have led to an increased capture of $\mathrm{N}$ that was moved to deeper soil layers. The lower proportion of weed $\mathrm{N}$ uptake covered by fertilizer $\mathrm{N}$ at crop maturity compared to crop flowering indicates an increased proportion in uptake of soil $\mathrm{N}$ when crop $\mathrm{N}$ demand decreased.

\subsection{Implications for Weed Management}

The differential responses of the two weed species, here representing two groups of weeds, imply consequences for weed management because excess $\mathrm{N}$ availability will favor weed growth, as demonstrated by a shift in proportional weed biomass after fertilization in our study. Thus, only the HNR species benefitted from increased $\mathrm{N}$ availability, whilst the RNR species did not. This implies that $\mathrm{N}$ fertilization should be considered with caution where the local weed flora holds many HNR type weeds. In order to evaluate whether weed species are of the HNR or RNR type, a systematic characterization of the most common weed species in terms of their $\mathrm{N}$ responses would be needed in the future. Furthermore, reducing the $\mathrm{N}$ availability to weeds by, e.g., fertilizer placement can reduce weed biomass accumulation and, in the longer run, also the soil seed bank $[48,49]$. As our study demonstrated, increasing $\mathrm{N}$ availability alters the competitive relationship between different weed species. Nitrophilic species have competitive advantages over oligotrophic species, particularly at high $\mathrm{N}$ levels, due to higher allocation of resources into shoot growth. While this competitive advantage is not evident at low $\mathrm{N}$ availability, this pattern was suggested to explain the dominance of nitrophilic species in N-rich cropping systems and also the general loss of weed species diversity [12,50]. Our study demonstrates that increased $\mathrm{N}$ availability alters the competitive advantage even within the group of nitrophilic species, leading to a shift of dominance of the more N-responsive species group. Because seed production is often related to biomass [51], the increased dominance can have long-term effects on the weed community composition due to over-proportional contribution to the soil seed bank by the dominating species, thus favoring weed species that are highly competitive for the available $\mathrm{N}$.

\section{Conclusions}

The weed species with high $\mathrm{N}$ responsiveness (i.e., C. album in this study) clearly benefitted from increased $\mathrm{N}$ availability and responded with increased biomass and $\mathrm{N}$ accumulation, while the weed species with reduced $\mathrm{N}$ responsiveness (i.e., Galeopsis spp.) was suppressed by the dominating highly N-responsive weed. Consequently, the highly $\mathrm{N}$-responsive weed strongly competed for fertilizer $\mathrm{N}$ in all crops and recovered similar amounts of fertilizer $\mathrm{N}$ compared to the crops, whilst crop performance was unaffected by $\mathrm{N}$ fertilization. This study indicates how altered $\mathrm{N}$ availability in cropping systems can affect the dominance amongst nitrophilic weed groups, favoring those species with increased $\mathrm{N}$ responsiveness. The findings from this study have implications for cultural weed management, especially for $\mathrm{N}$ management in fields with highly N-responsive weed species, but they require further verification under different environmental conditions and a systematic characterization of common weed species' $\mathrm{N}$ responses.

Author Contributions: Conceptualization, O.J. and M.W.; methodology, O.J. and J.A.; formal analysis, O.J.; investigation, O.J. and J.A.; resources, project administration and funding acquisition, M.W.; writing—original draft preparation, O.J.; writing—review and editing, J.A. and M.W. All authors have read and agreed to the published version of the manuscript.

Funding: This research was funded by European Union's Horizon 2020 research and innovation programme, grant number 727284

Data Availability Statement: The data presented in this study are openly available in FigShare at https:/ / doi.org/10.6084/m9.figshare.14350604.v1 (accessed on 1 April 2021).

Acknowledgments: We are grateful to the following persons for their help in the field sampling and laboratory work: Sunil Abeyasekera, Claes Davidsson, Ewa Magnuski and Helena Bötker. 
Conflicts of Interest: The authors declare no conflict of interest. The funders had no role in the design of the study; in the collection, analyses, or interpretation of data; in the writing of the manuscript, or in the decision to publish the results.

\section{Appendix A}

Table A1. Mean monthly temperature and precipitation sum for the 2017 growing season and the reference period 1961-1990.

\begin{tabular}{ccccc}
\hline & \multicolumn{2}{c}{ Mean Temperature $^{\circ} \mathbf{C}$} & \multicolumn{2}{c}{ Precipitation Sum (mm) } \\
\cline { 2 - 5 } Period & $\mathbf{2 0 1 7}$ & $\mathbf{1 9 6 1 - 1 9 9 0}^{*}$ & $\mathbf{2 0 1 7}$ & $\mathbf{1 9 6 1 - 1 9 9 0 ~ * ~}^{*}$ \\
\hline May & 9.9 & 10.2 & 10 & 33 \\
June & 14.2 & 14.9 & 38 & 45 \\
July & 16.0 & 16.3 & 22 & 70 \\
August & 15.2 & 15.2 & 50 & 58 \\
September & 11.9 & 10.8 & 45 & 49 \\
\hline
\end{tabular}

Source: Uppsala Funbo-Lövsta climate Station, Uppsala (Sweden). * Are historical monthly average for the period 1961-1990, accessed from SMHI (Sweden).

Table A2. $p$-values following analysis of variance of weed biomass and $\mathrm{N}$ accumulation $\left(\mathrm{g} \mathrm{m}^{-2}\right)$ in dependency of the experimental factors weed species, crop, N-level and sampling time, and their interactions, and absolute $\left(\mathrm{g} \mathrm{m}^{-2}\right)$ and relative (\%) amount of $\mathrm{N}$ derived from fertilizer (Ndff) in dependency of weed species, crop and sampling time, and their interactions. $p$-values smaller 0.05 are marked in bold.

\begin{tabular}{|c|c|c|c|c|}
\hline & Biomass Accumulation & $\mathbf{N}$ accumulation & Ndff & Ndff \\
\hline Species & $<0.001$ & $<0.001$ & $<0.001$ & 0.006 \\
\hline Crop & 0.001 & $<0.001$ & 0.912 & 0.014 \\
\hline N-level & 0.009 & $<0.001$ & - & - \\
\hline Sampling time & 0.887 & 0.581 & 0.768 & 0.004 \\
\hline Species $\times$ Crop & 0.030 & 0.028 & 0.018 & 0.704 \\
\hline Species $\times$ N-level & 0.032 & 0.038 & - & - \\
\hline Crop $\times$ N-level & 0.054 & 0.034 & - & - \\
\hline Species $\times$ Sampling time & 0.495 & 0.096 & 0.828 & 0.615 \\
\hline Crop $\times$ Sampling time & 0.067 & 0.163 & 0.216 & 0.055 \\
\hline N-level $\times$ Sampling time & 0.018 & 0.049 & - & . \\
\hline Species $\times$ Crop $\times$ N-level & 0.060 & 0.070 & - & . \\
\hline Species $\times$ Crop $\times$ Sampling time & 0.169 & 0.137 & 0.720 & 0.663 \\
\hline Species $\times$ N-level $\times$ Sampling time & 0.118 & 0.103 & . & . \\
\hline Crop $\times$ N-level $\times$ Sampling time & 0.613 & 0.608 & . & . \\
\hline Species $\times$ Crop $\times$ N-level $\times$ Sampling time & 0.961 & 0.940 & . & . \\
\hline
\end{tabular}

Table A3. Estimates of ln-transformed mean biomass, $\mathrm{N}$ accumulation and absolute amount of $\mathrm{N}$ derived from fertilizer (Ndff) of Chenopodium album, Galeopsis spp. and the remaining weeds corresponding to back-transformed medians presented in Table 3. Different letters indicate significant differences between the species following pairwise comparison (Tukey, $\alpha=0.05$ ) based on ln-transformed data. Standard errors are given in parenthesis.

\begin{tabular}{cccc}
\hline & C. album & Galeopsis spp. & Remaining Weeds \\
\hline Biomass & $3.32(0.232)^{\mathrm{b}}$ & $1.42(0.245)^{\mathrm{a}}$ & $1.40(0.236)^{\mathrm{a}}$ \\
Accumulated N & $-0.31(0.192)^{\mathrm{b}}$ & $-2.43(0.200)^{\mathrm{a}}$ & $-2.266(0.192)^{\mathrm{a}}$ \\
Ndff & $-0.44(0.263)^{\mathrm{b}}$ & $-2.80(0.276)^{\mathrm{a}}$ & $-3.02(0.273)^{\mathrm{a}}$ \\
\hline
\end{tabular}


Table A4. Accumulated $\mathrm{N}$ derived from the soil (Ndfs) and fertilizer (Ndff) in the fertilized treatments of crops separated by species. Back-transformed means estimating medians and standard errors are presented for Ndfs and Ndff, which were obtained via the delta method. The original estimates based on ln-transformed data are presented in Table A5. Mean values of Ndfs and Ndff are averaged over sampling time (flowering, maturity; thereby $n=6$ ) due to non-significance of this factor in the analysis of variance. Mean values of Ndfa are averaged over the factor N-level $(n=6)$. Different letters within each group of $\mathrm{N}$ sources indicate significant different mean values following pairwise comparison with Tukey adjustment $(\alpha=0.05) .{ }^{*}$ One plot (fertilized intercrop at flowering) had to be removed from analyses due to missing $\mathrm{N}$ analysis.

\begin{tabular}{|c|c|c|c|c|}
\hline N Source & Species & $\begin{array}{l}\text { Sole Crop Barley } \\
\quad \mathrm{N}\left(\mathrm{g} \mathrm{m}^{-2}\right)\end{array}$ & $\begin{array}{c}\text { Pea-Barley Intercrop } \\
\mathrm{N}\left(\mathrm{g} \mathrm{m}^{-2}\right)\end{array}$ & $\begin{array}{l}\text { Sole-Crop Pea } \\
\quad \mathrm{N}\left(\mathrm{g} \mathrm{m}^{-2}\right)\end{array}$ \\
\hline \multirow{5}{*}{$\begin{array}{l}\text { Ndfs } \\
\left(\mathrm{g} \mathrm{m}^{-2}\right)\end{array}$} & Barley & $8.602(2.7659) \mathrm{g}$ & $7.567(2.4332)^{\mathrm{fg}}$ & - \\
\hline & Pea & - & $0.789(0.2536) \mathrm{de}$ & $5.18(1.6655) \mathrm{fg}$ \\
\hline & C. album & $0.678(0.2180)$ de & $0.581(0.2054)$ cde & $1.625(0.5226)$ ef \\
\hline & Galeopsis spp. & $0.054(0.0173)^{a b}$ & $0.102(0.0416)^{a b c}$ & $0.026(0.0083)^{\mathrm{a}}$ \\
\hline & weeds & $0.041(0.0130)^{a b}$ & $0.055(0.0193)^{a b}$ & $0.180(0.0579) \mathrm{bcd}$ \\
\hline \multirow{5}{*}{$\begin{array}{c}\text { Ndff } \\
\left(\mathrm{g} \mathrm{m}^{-2}\right)\end{array}$} & Barley & $1.974(0.7074)^{f}$ & $1.382(0.4953)^{f}$ & - \\
\hline & Pea & - & $0.181(0.0650)$ bcde & $1.188(0.4260)^{f}$ \\
\hline & C. album & $0.547(0.19861)$ def & $0.478(0.1897)$ cdef & $0.952(0.3412)$ ef \\
\hline & Galeopsis spp. & $0.082(0.0294)^{a b c}$ & $0.125(0.0575)$ abcde & $0.022(0.0080)^{\mathrm{a}}$ \\
\hline & weeds & $0.036(0.0127)^{a b}$ & $0.034(0.0135)^{\mathrm{ab}}$ & $0.113(0.0405)^{a b c d}$ \\
\hline \multirow{2}{*}{$\begin{array}{l}\mathrm{Ndfa} \\
\left(\mathrm{g} \mathrm{m}^{-2}\right)\end{array}$} & Pea flowering & & $1.09(0.909)^{a}$ & $1.98(0.771)^{\mathrm{a}}$ \\
\hline & Pea maturity & & $1.57(0.771)^{\mathrm{a}}$ & $6.11(0.771)^{b}$ \\
\hline
\end{tabular}

Table A5. Estimates of ln-transformed average accumulated N derived from the soil (Ndfs) and fertilizer (Ndff) in the fertilized treatments of crops separated by species. The presented values correspond to the back-transformed medians presented in Table A4. Values presented in parenthesis are standard errors. Mean values of Ndfs and Ndff are averaged over sampling time (flowering, maturity; thereby $n=6$ ) due to non-significance of this factor in the analysis of variance. Mean values of Ndfa are averaged over the factor N-level $(n=6)$. Different letters within each group of $\mathrm{N}$ sources indicate significant different mean values following pairwise comparison with Tukey adjustment $(\alpha=0.05)$.

\begin{tabular}{|c|c|c|c|c|}
\hline N Source & Species & $\begin{array}{l}\text { Sole Crop Barley } \\
\quad N\left(\mathrm{~g} \mathrm{~m}^{-2}\right)\end{array}$ & $\begin{array}{c}\text { Pea-Barley Intercrop } \\
\quad \mathrm{N}\left(\mathrm{g} \mathrm{m}^{-2}\right)\end{array}$ & $\begin{array}{l}\text { Sole-Crop Pea } \\
\quad \mathrm{N}\left(\mathrm{g} \mathrm{m}^{-2}\right)\end{array}$ \\
\hline \multirow{5}{*}{$\begin{array}{c}\text { Ndfs } \\
\left(\mathrm{g} \mathrm{m}^{-2}\right)\end{array}$} & Barley & $2.15(0.328)^{g}$ & $2.09(0.360) \mathrm{fg}$ & - \\
\hline & Pea & - & $-0.25(0.360)$ de & $1.65(0.328) \mathrm{fg}$ \\
\hline & C. album & $-0.39(0.328) \mathrm{de}$ & $-0.54(0.360)$ cde & $0.49(0.328)$ ef \\
\hline & Galeopsis spp. & $-2.93(0.328)^{a b}$ & $-2.29(0.415)^{a b c}$ & $-3.66(0.328)^{\mathrm{a}}$ \\
\hline & weeds & $-3.21(0.328)^{a b}$ & $-3.06(0.402)^{a b}$ & $-1.71(0.328) b c d$ \\
\hline \multirow{5}{*}{$\begin{array}{c}\text { Ndff } \\
\left(\mathrm{g} \mathrm{m}^{-2}\right)\end{array}$} & Barley & $0.68(0.367)^{f}$ & $0.34(0.405)^{f}$ & - \\
\hline & Pea & - & $-1.83(0.405)$ bcde & $0.17(0.367)^{f}$ \\
\hline & C. album & $-0.60(0.367)$ def & $-0.75(0.405)$ cdef & $-0.05(0.367))^{e f}$ \\
\hline & Galeopsis spp. & $-2.50(0.367)^{a b c}$ & $-2.11(0.469)$ abcde & $-3.80(0.367)^{\mathrm{a}}$ \\
\hline & weeds & $-3.34(0.367) \mathrm{ab}$ & $-3.54(0.454)^{a b}$ & $-2.18(0.367)$ abcd \\
\hline
\end{tabular}

Table A6. $p$-values following analysis of variance of crop grain yields ( $\mathrm{kg} \mathrm{DM} \mathrm{ha}^{-1}$ ) and relative (\%) and absolute amount $\left(\mathrm{g} \mathrm{m}^{-2}\right)$ of $\mathrm{N}$ derived from air (Ndfa) in pea in dependency of the crop mixture (as sole-crop or intercrop), N-level, sampling time (flowering and maturity) and their interactions. $p$-values smaller 0.05 are marked in bold.

\begin{tabular}{ccccc}
\hline & Grain Yield & & Ndfa \\
\cline { 2 - 5 } & Barley & Pea & \% & $\mathbf{g ~ m}^{-\mathbf{2}}$ \\
\hline Crop mixture & $\mathbf{0 . 0 1 8}$ & $\mathbf{0 . 0 0 2}$ & 0.075 & $\mathbf{0 . 0 0 4}$ \\
N-level & 0.480 & 0.314 & 0.635 & 0.630 \\
Crop mixture $\times$ N-level & 0.838 & 0.699 & 0.739 & 0.985 \\
Sampling time & & & $\mathbf{0 . 0 2 5}$ & $\mathbf{0 . 0 1 1}$ \\
\hline
\end{tabular}


Table A6. Cont.

\begin{tabular}{ccccc}
\hline & Grain Yield & & Ndfa \\
\cline { 2 - 4 } & Barley & Pea & \% & g m ${ }^{-\mathbf{2}}$ \\
\hline Crop mixture $\times$ sampling time & & 0.567 & $\mathbf{0 . 0 3 7}$ \\
N-level $\times$ sampling time & & 0.547 & 0.985 \\
Crop mixture $\times$ N-level $\times$ & 0.966 & 0.868 \\
sampling time & & & \\
\hline
\end{tabular}

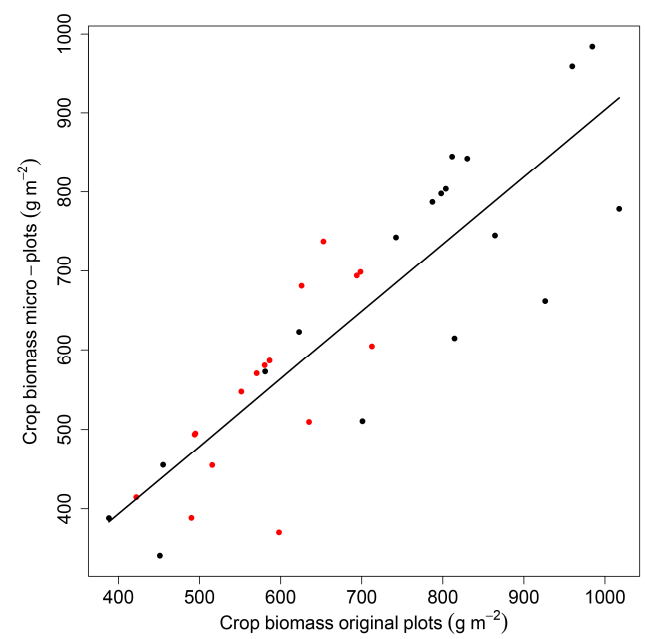

Figure A1. Relationship of crop biomass measured in the established micro-plots designated for ${ }^{15} \mathrm{~N}$-enrichment and natural abundance technique and crop biomass measured in the original plots where also the crop canopy parameters were measured. Marginal $\mathrm{R}^{2}=0.78$. Red symbols: crop biomass at crop flowering, black symbols: crop biomass at crop maturity.
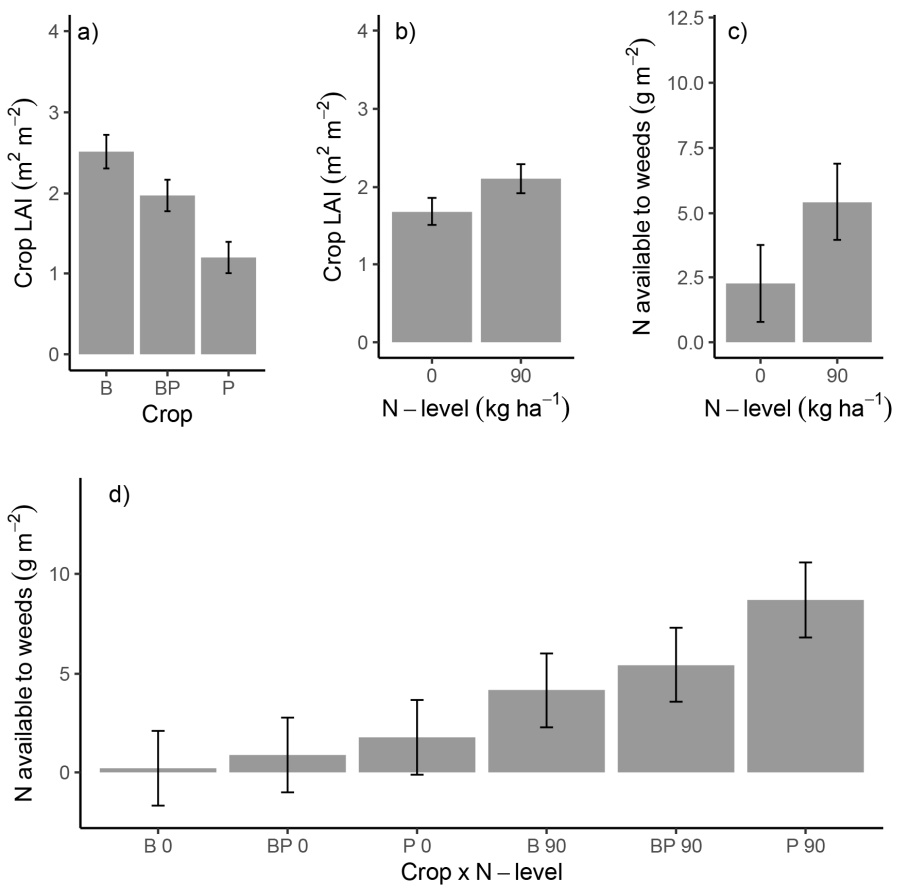

Figure A2. Crop LAI $(\mathbf{a}, \mathbf{b})$ and $\mathrm{N}$ available to weeds (c) in dependency of crop and $\mathrm{N}$ level at crop flowering and seasonal $\mathrm{N}$ availability to weeds along the series of cropping arrangements (d). B: sole-crop barley; BP: pea-barley intercrop; P: sole-crop pea; 0: $0 \mathrm{~kg} \mathrm{~N} \mathrm{ha}^{-1}$; 90: $90 \mathrm{~kg} \mathrm{~N} \mathrm{ha}^{-1}$. Error bars display standard errors. 


\section{References}

1. MacLaren, C.; Storkey, J.; Menegat, A.; Metcalfe, H.; Dehnen-Schmutz, K. An ecological future for weed science to sustain crop production and the environment. A review. Agron. Sustain. Dev. 2020, 40, 24. [CrossRef]

2. Martin-Guay, M.O.; Paquette, A.; Dupras, J.; Rivest, D. The new Green Revolution: Sustainable intensification of agriculture by intercropping. Sci. Total Environ. 2018, 615, 767-772. [CrossRef] [PubMed]

3. Jensen, E.S.; Carlsson, G.; Hauggaard-Nielsen, H. Intercropping of grain legumes and cereals improves the use of soil N resources and reduces the requirement for synthetic fertilizer N: A global-scale analysis. Agron. Sustain. Dev. 2020, 40, 5. [CrossRef]

4. Hauggaard-Nielsen, H.; Ambus, P.; Jensen, E.S. Interspecifc competition, N use and interference with weeds in pea-barley intercropping. Field Crops Res. 2001, 70, 101-109. [CrossRef]

5. Corre-Hellou, G.; Dibet, A.; Hauggaard-nielsen, H.; Crozat, Y.; Gooding, M.; Ambus, P. The competitive ability of pea-Barley intercrops against weeds and the interactions with crop productivity and soil N availability. Field Crops Res. 2011, 122, 264-272 [CrossRef]

6. Bedoussac, L.; Journet, E.; Hauggaard-nielsen, H.; Naudin, C.; Corre-hellou, G.; Jensen, E.S. Ecological principles underlying the increase of productivity achieved by cereal-grain legume intercrops in organic farming. A review. Agron. Sustain. Dev. 2015, 35, 911-935. [CrossRef]

7. Radosevic, S.R.; Holt, J.S.; Ghersa, C.M. Ecology of Weeds and Invasive Plants: Relationship to Agriculture and Natural Resource Management, 3rd ed.; John Wiley \& Sons, Inc.: Hoboken, NJ, USA, 2007.

8. Grime, J.P. Plant Strategies, Vegetation Processes, and Ecosystem Proporties, 2nd ed.; John Wiley \& Sons Ltd.: Chichester, UK, 2001; ISBN 0-471-49601-4.

9. Storkey, J. A functional group approach to the management of UK arable weeds to support biological diversity. Weed Res. 2006, 46, 513-522. [CrossRef]

10. Gaba, S.; Perronne, R.; Fried, G.; Gardarin, A.; Bretagnolle, F.; Colbach, N.; Cordeau, S.; Andez-aparicio, M.F.; Gauvrit, C.; Guillemin, J.; et al. Response and effect traits of arable weeds in agro-ecosystems: A review of current knowledge. Weed Res. 2017, 57, 123-147. [CrossRef]

11. Storkey, J.; Moss, S.R.; Cussans, J.W. Using assembly theory to explain changes in a weed flora in response to agricultural intensification. Weed Sci. 2010, 58, 39-46. [CrossRef]

12. Moreau, D.; Busset, H.; Matejicek, A.; Munier-Jolain, N. The ecophysiological determinants of nitrophily in annual weed species. Weed Res. 2014, 54, 335-346. [CrossRef]

13. Blackshaw, R.E.; Brandt, R.N.; Janzen, H.H.; Entz, T.; Grant, C.A.; Derksen, D.A. Differential response of weed species to added nitrogen. Weed Sci. 2003, 51, 532-539. [CrossRef]

14. Bostrom, U.; Milberg, P.; Fogelfors, H. Yield loss in spring-sown cereals related to the weed flora in the spring. Weed Sci. 2018, 51, 418-424. [CrossRef]

15. Milberg, P.; Hallgren, E.; Palmer, M.W. Interannual variation in weed biomass on arable land in Sweden. Weed Res. 2000, 40, 311-321. [CrossRef]

16. Ellenberg, H.; Weber, H.E.; Düll, R.; Wirth, V.; Werner, W. Zeigerwerte von Pflanzen in Mitteleuropa/Indicator Values of Plants in Central Europe, 3rd ed.; Erich Golze GmbH: Göttingen, Germany, 2001; ISBN 3-88452-518-2.

17. Meier, U. Growth Stages of Mono- and Dicotyledonous Plants. BBCH Monograph; Blackwell Wissenschafts-Verlag: Berlin, Germany; Wien, Austria, 1997; ISBN 9783955470715.

18. Pierozan Junior, C.; Jackson, K. Efficiency of the leaf disc method for estimating the leaf area index of soybean plants. Acta Sci. Agron. 2013, 35, 487-493. [CrossRef]

19. Werner, R.A.; Bruch, B.A.; Brand, W.A. ConFlo III-An interface for high precision d $13 \mathrm{C}$ and d $15 \mathrm{~N}$ analysis with an extended dynamic range. Rapid Commun. Mass Spectrom. 1999, 13, 1237-1241. [CrossRef]

20. Shearer, G.; Kohl, D.H. N2-Fixation in field settings: Estimations based on natural 15N abundance. Aust. J. Plant Physiol. 1986, 13, 699-756.

21. Hauggaard-Nielsen, H.; Ambus, P.; Jensen, E.S. The comparison of nitrogen use and leaching in sole cropped versus intercropped pea and barley. Nutr. Cycl. Agroecosys. 2003, 65, 289-300. [CrossRef]

22. Fried, M.; Middelboe, V. Measurement of amount of nitrogen fixed by a legume crop. Plant Soil 1977, 47, 713-715. [CrossRef]

23. Onofri, A.; Carbonell, E.A.; Piepho, H.P.; Mortimer, A.M.; Cousens, R.D. Current statistical issues in weed research. Weed Res. 2010, 50, 5-24. [CrossRef]

24. R Core Team. R: A Language and Environment for Statistical Computing; R Foundation for Statistical Computing: Vienna, Austria, 2013.

25. Bates, D.; Mächler, M.; Bolker, B.M.; Walker, S.C. Fitting linear mixed-effects models using lme4. J. Stat. Softw. 2015, 67, 1-48. [CrossRef]

26. Kutznetsova, A.; Brockhoff, P.B.; Christensen, R.H.B. lmerTest Package: Tests in Linear Mixed Effects Models. J. Stat. Softw. 2017, 82, 1-26. [CrossRef]

27. Lenth, R. Emmeans: Estimated Marginal Means, aka Least-Squares Means; R Package Version 1.4.3.01; R Foundation for Statistical Computing: Vienna, Austria, 2019.

28. Nakagawa, S.; Schielzeth, H. A general and simple method for obtaining R2 from generalized linear mixed-effects models. Methods Ecol. Evol. 2013, 4, 133-142. [CrossRef] 
29. Lüdecke, D.; Makowski, D.; Waggoner, P. Performance: Assessment of Regression Models Performance, R package version 0.4.0; R Foundation for Statistical Computing: Vienna, Austria, 2019.

30. Corre-Hellou, G.; Brisson, N.; Launay, M.; Fustec, J.; Crozat, Y. Effect of root depth penetration on soil nitrogen competitive interactions and dry matter production in pea-Barley intercrops given different soil nitrogen supplies. Field Crops Res. 2007, 103, 76-85. [CrossRef]

31. Hauggaard-Nielsen, H.; Ambus, P.; Jensen, E.S. Temporal and spatial distribution of roots and competition for nitrogen in pea-barley intercrops-A field study employing $32 \mathrm{P}$ technique. Plant Soil 2001, 63, 63-74. [CrossRef]

32. Jensen, E.S. Grain yield, symbiotic N2 fixation and interspecific competition for inorganic N in pea-barley intercrops. Plant Soil 1996, 182, 25-38. [CrossRef]

33. Ghaley, B.B.; Jensen, E.S. Intercropping of wheat and pea as influenced by nitrogen fertilization. Nutr. Cycl. Agroecosyst. 2005, 73, 201-212. [CrossRef]

34. Voisin, A.; Salon, C.; Munier-jolain, N.G.; Ney, B. Quantitative effects of soil nitrate, growth potential and phenology on symbiotic nitrogen fixation of pea (Pisum sativum L.). Plant Soil 2002, 243, 31-42. [CrossRef]

35. Naudin, C.; Corre-Hellou, G.; Pineau, S.; Crozat, Y.; Jeuffroy, M.H. The effect of various dynamics of N availability on winter pea-wheat intercrops: Crop growth, N partitioning and symbiotic N2 fixation. Field Crops Res. 2010, 119, 2-11. [CrossRef]

36. Håkansson, S. Seasonal variation in the emergence of annual weeds-An introductory investigation in Sweden. Weed Res. 1983, 23, 313-324. [CrossRef]

37. Pakeman, R.J.; Karley, A.J.; Newton, A.C.; Morcillo, L.; Brooker, R.W.; Schöb, C. A trait-based approach to crop-Weed interactions. Eur. J. Agron. 2015, 70, 22-32. [CrossRef]

38. Engström, L.; Lindén, B. Importance of soil mineral $\mathrm{N}$ in early spring and subsequent net $\mathrm{N}$ mineralisation for winter wheat following winter oilseed rape and peas in a milder climate. Acta Agric. Scand. Sect. B Soil Plant Sci. 2009, 59, 402-413. [CrossRef]

39. Nagel, K.A.; Kastenholz, B.; Jahnke, S.; Van Dusschoten, D.; Aach, T.; Mühlich, M.; Truhn, D.; Scharr, H.; Terjung, S.; Walter, A.; et al. Temperature responses of roots: Impact on growth, root system architecture and implications for phenotyping. Funct. Plant Biol. 2009, 36, 947-959. [CrossRef] [PubMed]

40. Glendining, M.J.; Poulton, P.R.; Powlson, D.S.; Jenkinson, D.S. Fate of 15 N-labelled fertilizer applied to spring barley grown on soils of contrasting nutrient status. Plant Soil 1997, 195, 83-98. [CrossRef]

41. Glass, A.D.M. Nitrogen use efficiency of crop plants: Physiological constraints upon nitrogen absorption. CRC Crit. Rev. Plant. Sci. 2003, 22, 453-470. [CrossRef]

42. Thomsen, I.K.; Christensen, B.T. Fertilizer N recovery in cereal crops and soil under shallow tillage. Soil Tillage Res. 2007, 97, 117-121. [CrossRef]

43. Schenk, H.J. Root competition: Beyond resource depletion. J. Ecol. 2006, 94, 725-739. [CrossRef]

44. Craine, J.M.; Dybzinski, R. Mechanisms of plant competition for nutrients, water and light. Funct. Ecol. 2013, 27, 833-840. [CrossRef]

45. Kiær, L.P.; Weisbach, A.N.; Weiner, J. Root and shoot competition: A meta-analysis. J. Ecol. 2013, 101, 1298-1312. [CrossRef]

46. Schwinning, S.; Weiner, J. Mechanisms determining the degree of size asymmetry in competition among plants. Oecologia 1998, 113, 447-455. [CrossRef]

47. Blackshaw, R.E.; Brandt, R.N. Nitrogen fertilizer rate effects on weed competitiveness is species dependent. Weed Sci. 2008, 56, 743-747. [CrossRef]

48. Blackshaw, R.E.; Molnar, L.J.; Janzen, H.H. Nitrogen fertilizer timing and application method affect weed growth and competition with spring wheat. Weed Sci. 2004, 52, 614-622. [CrossRef]

49. Petersen, J. Weed:spring barley competition for applied nitrogen in pig slurry. Weed Res. 2003, 43, 33-39. [CrossRef]

50. Moss, S.R.; Storkey, J.; Cussans, J.W.; Perryman, S.A.M.; Hewitt, M.V. Symposium The Broadbalk long-term experiment at Rothamsted: What has it told us about weeds? Weed Sci. 2004, 52, 864-873. [CrossRef]

51. Younginger, B.S.; Sirová, D.; Cruzan, M.B.; Ballhorn, D.J. Is biomass a reliable estimate of plant fitness? Appl. Plant. Sci. 2017, 5, 1600094. [CrossRef] [PubMed] 